\title{
Smoke Generation Parameters from the Cone Calorimeter Method and Single-Chamber Test ${ }^{\dagger}$
}

\author{
Adriana Małgorzata Dowbysz * (D) and Mariola Samsonowicz (D)
}

Citation: Dowbysz, A.M.;

Samsonowicz, M. Smoke Generation

Parameters from the Cone

Calorimeter Method and

Single-Chamber Test. Environ. Sci.

Proc. 2021, 9, 22. https://doi.org/

10.3390/environsciproc2021009022

Academic Editors: Dorota

Anna Krawczyk, Iwona Skoczko,

Antonio Rodero Serrano and

Ewa Szatyłowicz

Published: 1 November 2021

Publisher's Note: MDPI stays neutral with regard to jurisdictional claims in published maps and institutional affiliations.

Copyright: (c) 2021 by the authors. Licensee MDPI, Basel, Switzerland. This article is an open access article distributed under the terms and conditions of the Creative Commons Attribution (CC BY) license (https:/ / creativecommons.org/licenses/by/ $4.0 /)$.
Department of Chemistry, Biology and Biotechnology, Bialystok University of Technology, Wiejska 45A Street, 15-351 Bialystok, Poland; m.samsonowicz@pb.edu.pl

* Correspondence: a.prusinowska@doktoranci.pb.edu.pl; Tel.: +48-571-443-161

+ Presented at Innovations-Sustainability-Modernity-Openness Conference (ISMO'21), Bialystok, Poland, 14 May 2021.

Abstract: Smoke generated in the combustion process of plastics reduces visibility and contains toxic products causing severe health problems for and may be hazardous to both people and the environment. Therefore, the awareness of smoke specification is important. This paper presents two most common small-scale methods for measuring smoke parameters. The cone calorimeter method and single-chamber test, respectively, standardized by ISO 5660 and PN-EN ISO 5659-2 were reviewed. Fundamentals of these methods and measurement techniques were described. Di-verse smoke parameters obtained from these methods were collected and specified. Attention was also drawn to the relevance of these parameters to standard requirements for various industry fields such as rail transport or shipbuilding.

Keywords: cone calorimeter; smoke chamber; smoke parameters; smoke extinction area; smoke density

\section{Introduction}

Plastics are very common and versatile materials. Their global production reaches 300 million tons annually. Plastics have many advantages such as longevity, degradation resistance, inertness, ease of forming and low production cost, therefore they play an important role in everyday use [1].

Unfortunately, plastics are readily combustible in fire conditions and their combustion process generates smoke and toxic products which may have a negative impact on people and the environment [2].

Smoke consists of gases, vapours and particulates, specifically microdroplets formed from condensed organic vapours as well as soot from carbonaceous agglomerated structures [3]. Besides generating toxic gases, smoke shows an incapacitating effect by reducing visibility, resulting in failures escaping from fire [4].

Therefore, an analysis of smoke parameters is crucial for providing fire safety. This paper describes two most common small-scale methods for measuring smoke parameters: cone calorimeter method and single-chamber test. Smoke parameters obtained from these methods have been specified and their usage in rail transport and shipbuilding have been presented.

\section{Cone Calorimeter Method}

This method is very common in the field of fire testing. It can be conducted in accordance with ISO 5660 or ASTM E1354. Cone calorimeter measures mass loss rate, emissions and heat release rate (HRR) at the same time [5]. Smoke measurement is based 
on the Bouguer's law, which describes the attenuation of a beam light in combustion products [6]. The Equation (1) is given below.

$$
\mathrm{I} / \mathrm{I}_{0}=\exp (-\mathrm{k} \cdot \mathrm{L}),
$$

where I [-] and $\mathrm{I}_{0}[-]$ are, respectively, overall light intensity and initial overall light intensity, $\mathrm{k}\left[\mathrm{m}^{-1}\right]$ is the extinction coefficient and $\mathrm{L}[\mathrm{m}]$ is the length of the light beam [7].

In the cone calorimeter, forced-fire conditions are stimulated. The specimen mounted under the cone heater is exposed to the controlled level of radiant heat. The measurement helps investigate thermal decomposition and vaporization of the specimen at different heat flux [8].

Smoke production rate (SPR) and total smoke production (TSP) are the basic smoke parameters measured by cone calorimeter. SPR $\left[\mathrm{m}^{2} / \mathrm{s}\right]$ may be expressed as the product of $\mathrm{k}\left[\mathrm{m}^{-1}\right]$ and $\mathrm{V}_{\mathrm{f}}\left[\mathrm{m}^{3} / \mathrm{s}\right]$, which is the volume flow rate through the duct. This measurement is not related to the specimen's mass [9]. An index dependent on SPR is SMOGRA $\left[\mathrm{m}^{2} / \mathrm{s}^{2}\right.$ ] defined as the maximum value of the ratio of SPR to time when it was measured [10].

SPR varies in periods of time. Thus, the TSP $\left[\mathrm{m}^{2}\right]$ or $\left[\mathrm{m}^{3} / \mathrm{m}\right]$ is also an important parameter for the comparison of materials. The summation of SPR is carried out until the end of the test.

A smoke parameter dependent on mass loss is the specific extinction area (SEA) which describes the amount of smoke generated per $1 \mathrm{~kg}$ of fuel during combustion [9]. Other important parameters are $\mathrm{CO}$ and $\mathrm{CO}_{2}$ yields, which describe the mass of particular gas per mass loss of fuel. They may be expressed in $[\mathrm{g} / \mathrm{kg}]$ or $[\mathrm{kg} / \mathrm{kg}][11]$.

\section{Single-Chamber Test}

Smoke density chamber is also common in fire testing. It can be conducted in accordance with ISO 5659-2 or ASTM E662 [12]. As distinct from the cone calorimeter, the smoke density chamber is made specifically for smoke measurements. It is used for monitoring smoke generation from burning materials and quantifying smoke obscuration [13].

During sample decomposition smoke is accumulated in the chamber. The attenuation of the light beam is measured according to Bouguer's law (1). Smoke density D [-] is calculated according to Equation (2) [14]:

$$
\mathrm{D}=\log \mathrm{I}_{0} / \mathrm{I},
$$

This parameter is dependent on the sample geometry. Therefore, specific optical density $D_{S}[-]$ is used more often. The equation is as follows:

$$
\mathrm{D}_{\mathrm{s}}=\mathrm{D} \cdot \mathrm{V} / \mathrm{A} \cdot \mathrm{L},
$$

where $\mathrm{V}\left[\mathrm{m}^{3}\right]$ is the chamber volume, $\mathrm{A}\left[\mathrm{m}^{2}\right]$ is the exposed area of the specimen, $\mathrm{L}[\mathrm{m}]$ is the path length of the light beam, $\mathrm{I}_{0}[-]$ and I [-] are the intensities of the light beam, respectively, before and during the test [15].

There are two important values of specific optical density $D_{s}$ measured during the test: the maximum value of specific optical density $D_{s} \max$ and specific optical density at 4th minute of measurement $D_{s}(4)$ [16]. Another parameter related to $D_{s}$ is $\operatorname{VOF}(4)$ which is defined as the area under curve of specific optical density during the first 4 minutes of measurement [17].

Information about the overall toxicity of analysed gases may be provided by the Conventional Index of Toxicity $\mathrm{CIT}_{G}[-]$ obtained by connecting the FTIR analyzer to the smoke chamber. The concentration of eight toxic gases such as $\mathrm{CO}_{2}, \mathrm{CO}, \mathrm{HF}, \mathrm{HCl}, \mathrm{HCN}$, $\mathrm{NO}_{\mathrm{x}}, \mathrm{SO}_{2}$ and $\mathrm{HBr}$ is measured during the test [18]. 


\section{Relevance of Smoke Parameters to Standard Requirements}

The presented smoke parameters obtained from the cone calorimeter and smoke density chamber may be used for classifying materials in terms of fire protection. They are used in some industry fields such as rail transport or shipbuilding.

A European standard relevant to rolling stock is EN 45545-2:2020 Railway applicationsfire protection on railway vehicles. In Part 2, requirements for firebehaviour of materials and components are specified, which vary depending on the operation and design category of the train. Smoke parameters obtained from the cone calorimeter are not mentioned in rolling stock requirements. The single chamber test is more usable and provide parameters such as $\mathrm{D}_{\mathrm{s} \text { max }}, \mathrm{D}_{\mathrm{s}}(4), \mathrm{VOF}(4)$ and $\mathrm{CIT}_{\mathrm{G}}[19]$.

In shipbuilding it is mandatory to meet the requirements of the International Code for Application of Fire Test Procedures (FTP). The classifying criterion for smoke generation test is $D_{m}[-]$, which is an average value of the $D_{s} \max$ of each of three tests. Toxic gases and vapours are also measured in the smoke chamber by adding the Fourier Transform Infrared (FTIR) module. The smoke parameter obtained from the cone calorimeter, which is used in requirements for high-speed craft materials, is the average value of SPR [20].

\section{Conclusions}

The most common small-scale tests for measuring smoke generated from plastics are the cone calorimeter method and the single-chamber test. Materials used in rail transport or shipbuilding have to positively pass the assessment of diverse parameters, including those associated with smoke generation.

In rail transport the cone calorimeter method provides information only on heat emission. Smoke parameters are measured using the single-chamber test. Depending on the requirement set, $D_{s}(4), \operatorname{VOF}(4)$ or $D_{s \text { max }}$ are used. Toxicity of smoke is represented by $\mathrm{CIT}_{\mathrm{G}}$ obtained also from the smoke chamber.

The main smoke parameter crucial in shipbuilding is $D_{m}$ dependent on $D_{s} \max$. The analysis of toxic gases and vapours may be held with the additional usage of the FTIR module. The cone calorimeter method is used in high-speed crafts, and, besides heat parameters, there is only SPR related to smoke generation.

Thus, there are more smoke parameters obtained from the smoke density chamber than from the cone calorimeter in standard requirements.

Author Contributions: A.P. wrote original draft, M.S. reviewed and edited the paper. All authors have read and agreed to the published version of the manuscript.

Acknowledgments: The research was financed by Bialystok University of Technology.

Conflicts of Interest: The authors declare no conflict of interest. The founding sponsors had no role in the design of the study; in the collection, analyses, or interpretation of data; in the writing of the manuscript, and in the decision to publish the results.

\section{References}

1. Bajt, O. From plastics to microplastics and organisms. FEBS Open Biol. 2020, 4, 1-28.

2. Simoneit, B.R.; Medeiros, P.M.; Didyk, B.M. Combustion Products of Plastics as Indicators for Refuse Burning in the Atmosphere. Environ. Sci. Technol. 2005, 39, 6961-6970. [CrossRef] [PubMed]

3. Butler, K.M.; Mulholland, G.W. Generation and Transport of Smoke Components. Fire Technol. 2004, 40, 149-176. [CrossRef]

4. Stec, A.A. Fire Toxicity-The Elephant in the Room? Fire Saf. J. 2017, 91, 79-90. [CrossRef]

5. Brohez, S.; Delvosalle, C.; Marlair, G.; Tewarson, A. The Measurement of Heat Release from Oxygen Consumption in Sooty Fires. J. Fire Sci. 2000, 18, 327-353. [CrossRef]

6. ISO 5660-1:2015 Reaction-to-Fire Tests-Heat Release, Smoke Production and Mass Loss Rate-Part 1: Heat Release Rate (Cone Calorimeter Method) and Smoke Production Rate (Dynamic Measurement); International Organization for Standardization: Geneva, Switzerland, 2015.

7. Tissot, J.; Talbaut, M.; Yon, J.; Coppalle, A.; Bescond, A. Spectral Study of the Smoke Optical Density in Non-Flaming Condition. In Proceedings of the 9th Asia-Oceania Symposium on Fire Science and Technology, Hefei, China, 17-20 October 2012; Volume 62, pp. 821-828. 
8. Das, O.; Kim, N.K.; Hedenqvist, M.S.; Bhattacharyya, D. 15-The flammability od biocomposites. In Durability and Life Prediction in Biocomposites, Fibre-Reinforced Composites and Hybrid Composites; Jawaid, M., Thariq, M., Saba, N., Eds.; Woodhead Publishing: Duxford, UK, 2019; pp. 335-365.

9. Birgit, A.; Östman, L. Smoke and Soot. In Heat Release in Fires; Babrauskas, V., Grayson, S.J., Eds.; Elsevier Science Publishers: London, UK, 1992; pp. 236-245.

10. Hansen, A. No Fire without Smoke: Prediction Models for Heat Release and Smoke Production in the SBI Test and the Room Corner Test Based on Cone Calorimeter Test Results. Ph.D. Thesis, Norwegian University of Science and Technology, Trondheim, Norway, 2002.

11. Martinka, J.; Rantuch, P.; Wachter, I. Impact of Water Content on Energy Potential and Combustion Characteristics of Methanol and Ethanol Fuels. Energies 2019, 12, 3491. [CrossRef]

12. Lawson, J. A History of Fire Testing; National Institute of Standards and Technology: Gaithersburg, MD, USA, 2009 ; p. 25.

13. Stec, A.A.; Rhodes, J. Bench Scale Generation of Smoke Particulates and Hydrocarbons from Burning Polymers. In Proceedings of the Fire Safety Science-Tenth International Symposium, Baltimore, MA, USA, 19-24 June 2011; pp. 629-640.

14. Kolbrecki, A. O Dymotwórczości Wyrobów Budowlanych w Czasie Pożaru. Pr. Inst. Tech. Bud.-Kwart. $2000,4,50$.

15. Peacock, R.; Cleary, T.; Reneke, P.; Murphy, D.C. A Literature Review of the Effects of Smoke from a Fire on Electrical Equipment; National Institute of Standards and Technology: Gaithersburg, MD, USA, 2012; pp. 26-28.

16. Gregory, S.; Grayson, S.J.; Kumar, S. Test Methods and Instrumentation for Assessing Reaction to Fire Properties of Railway Rolling Stock. Probl. Kolejnictwa 2013, 160, 35-43.

17. Półka, M.; Szajewska, A. Smoke Emission Properties of Floor Covering Materials of Furnished Apartments in a Building. Int. J. Environ. Res. Public Health 2020, 17, 9019. [CrossRef] [PubMed]

18. Marset, D.; Dolza, C.; Fages, E.; Gonga, E.; Gutierrez, O.; Gomez-Caturla, J.; Ivorra-Martinez, J.; Sanchez-Nacher, L.; Quiles-Carillo, J. The Effect of Halloysite Nanotubes on the Fire Retardancy Properties of Partially Biobased Polyamide 610. Polymers 2020, 12, $1-21$.

19. EN 45545-2:2020 Railway Applications_Fire Protection on Railway Vehicles-Part 2: Requirements for Fire Behavior of Materials and Components; European Committee for Standardization: Brussels, Belgium, 2013.

20. International Code for Application of Fire Test Procedures (FTP Code); International Maritime Organization (IMO): London, UK, 2010. 